\title{
TINJAUAN YURIDIS UNDANG-UNDANG PEMERINTAHAN DAERAH TENTANG KEGIATAN PERTAMBANGAN
}

\author{
Eko Nuriyatman'1) , Trias Hernanda2) \\ 1)Pengamat Kebijakan Hukum Ligkungan \\ Perum Bambu Apung 2, Blok B.06, Desa Sungai Duren, Kec.Jaluko, Kab.Muaro Jambi \\ ekonuriyatman90@gmail.com \\ 2)Dosen Fakultas Hukum Universitas Muhammadiyah Kudus \\ Jln. Ganesha Raya No.I, Purwosari, Kecamatan Kota Kudus Kabupaten Kudus, Jawa Tengah \\ triashernanda@umkudus.ac.id
}

\begin{abstract}
This scientific article contains writings about the juridical review of local government law regarding mining activities in Indonesia. In this article the researcher discusses two things, namely the authority of the regional government in mining and inconsistencies between local government laws and coal mineral laws. The research method used in writing this article is a normative research method, the legal concept used is that proposed by Soetondyo Wigyosoebroto who has five legal concepts, but in this article the author uses the second and fifth concept concepts presented by Soetondyo Wigyosoebroto. Based on the results of writing this article, it is found that after the issuance of Law Number 23 of 2014 the authority to grant mining activities permits lies with the provincial government and this is contrary to what is contained in Law Number 4 of 2009, so that in the application of the lex principle applies specialis derogate legi generalisi. The development of mining activities that occur in Indonesia has a very large impact on mining activities, with the authority for mining activities having the aim that management of mining activities is not centralized and can increase the economy and increase local revenue.
\end{abstract}

Keyword: Regional Government, Mining, Licensing.

\begin{abstract}
Abstrak
Artikel ilmiah ini memuat tulisan mengenai tinjaun yuridis undang-undang pemerintahan daerah tentang kegiatan pertambangan yang ada di Indonesia. Dalam artikel ini peneliti membahas mengenai dua hal, yaitu kewenangan pemerintah daerah dalam hal pertambangan dan inkonsistensi antara undang-undang pemerintahan daerah terhadap undang-undang mineral batubara. Metode penelitian yang digunakan dalam penulisan artikel ini adalah metode penelitian normatif, konsep hukum yang digunakan adalah yang dikemukakan oleh Soetondyo Wigyosoebroto yang memiliki lima konsep hukum, namun dalam artikel ini penulis menggunakan konsep kedua dan kondep kelima yang dipaparkan oleh Soetondyo Wigyosoebroto. Berdasarkan hasil penulisan artikel ini di dapat data bahwa setelah terbitnya Undang-Undang Nomor 23 Tahun 2014 kewenangan pemberian izin kegiatan pertambangan berada pada pemerintah provinsi dan hal tersebut bertentangan dengan yang termuat di Undang-Undang Nomor 4 Tahun 2009, sehingga di dalam penerapannya berlakulah asas lex specialis derogate legi generalisi. Perkembangan kegiatan petambangan yang terjadi di Indonesia memberikan dampak yang sangat besar terhadap kegiatan pertambangan, dengan adanya kewenangan terhadap kegiatan pertambangan memiliki tujuan agar pengelolaan kegiatan pertambangan tidak terpusat dan dapat meningkatkan perekonomia dan meningkatkan pendapatan asli daerah.
\end{abstract}

Kata Kunci: Pemerintahan Daerah, Pertambangan, Perizinan. 


\section{Pendahuluan}

Kegiatan pertambangan merupakan sebuah kegiatan yang dilakukan oleh manusia di dalam mengolah sumber daya alam (SDA) meliputi air, udara, tanah dan kekayaan alam lainnya. Yang mana mengenai kekayaan alam ini di atur pula di dalam Pasal 33 ayat (3) Undang-Undang Dasar 1945 (UUD 1945) segala kekayaan alam dikuasai oleh nagara yang dapat dipergunakan untuk kemakmuran rakyat yang seluas-luasnya. Dalam pasal ini menyebutkan bahwa segala sesuatu yang terdapat didalamnya "dikuasai oleh negara" yang mana dalam kalimat tersebut menunjukkan konsep hak penguasaan negara yang diamanatkan di dalam konstituri.

Hal tersebut memerluka pengkajian yang cukup mendalam mengenai hak menguasai negara dan apa yang sebenarnya menjadi hak penguasaan oleh negara. Pengkajian ini menjadi penting dikarenakan untuk mengetahui dan memahami pokokpokok pikaran mengenai pandangan yang mempengaruhi serta maksud para pembuatnya dan semangat yang terkandung didalamnya. ${ }^{1}$ Hak penguasaan negara sebagai sebuah konsep belum dapat diterjemahkan dengan jelas dan tegas agar dapat diterima oleh seluruh pihak dalam hal pengelolaan dan pemanfaatan SDA nasional sehingga menimbang banyak penafsiran yang berimplikasi kepada implementasinya. ${ }^{2}$ Oleh sebab tersebut sangat diperlukan sebuah kajian yang mendalam mengenai hal tersebut.

Hak menguasai negara di jabarkan dalam Pasal 2 ayat (2) Undang-Undang Nomor 5 Tahun 1960 Tentang Peraturan Dasar Pokok-Pokok Agraria (UUPA), yang menyatakan bahwa konsep menguasai oleh

\footnotetext{
1 Muhammad Yamin, Naskah Persiapan Undang-Undang 1945, (Djakarta: Jilid Pertama (Cetakan Kedua), Siguntang, 1971), hlm. 301.

${ }^{2}$ H.Abrar Saleng, Hukum Pertambangan, (Jakarta: UII Press, 2004), hlm. 2.
}

negara bukan memiliki, melainkan hanya sebatas menguasai. Hal ini dapat kita pahami bahwa negara hanya memiliki suatu kewenangan untuk dapat mengurus mengenai kekayaan alam, air, udara dan tanah sebagaimana yang di maksud dalam Pasal 33 UUD 1945 tersebut. Namun sampai dengan saat ini kalimat "negara mengusai" masih dimaknai sebagai "negara mimiliki."

Berdasarkan Pasal 33 ayat (3) UUD 1945 terbentuklah Undang-Undang Nomor 4 Tahun 2009 Tentang Pertambangan Mineral dan Batu Bara (UU Minerba). Sebelum lahirnya UU Minerba terjadi dualisme pemahaman konsep "menguasai negara" antara Pasal 33 ayat (3) UUD 1945 dan UUPA, namun didalam UU Minerba mengubah konsep kontrak karya dimana pemerintah bertindak sebagai pihak yang sejajar kedudukannya dengan perusahaan pertambangan karena pemahaman konsep penguasaan negara yang mana negara menguasai semua bahan galian dengan sepenuh-penuhnya untuk kepentingan negara serta kemakmuran rakyat karena bahanbahan galian tersebut merupakan kekayaan nasional.

Kegiatan usaha pertambangan dipergunakan untuk mengelola bahan galian yang ada di dalam bumi maupun di permukanaan dikarenakan pertambangan merupakan sala satu SDA yang sangat potensial dalam rangka peningkatan devisa dalam hal pembangunan nasional. Oleh sebab itu, industri pertambangan memberikan andil yang sangat besar dalam hal pertumbuhan perekonomian di Indonesia secara umum dan di daerah-daerah secara khusus dalam hal pengelolaan usaha pertambangan.

Namun perlu pula dipahami oleh seluruh masyarakat maupun pemerintah bahwa dari setiap kegiatan pertambangan pasti memberikan dampak positif maupun dampak negatif terhadap lingkungan sekitar seperti dapat terjadinya menurunya resapan air yang dapat mengganggu resapan tanah, sendimentasi, gerakan tanah/longsor dan pastinya akan terganggunya kehidupan flora maupun fauna di daerah tersebut. Maka dari 
itu diperlukan analisis mengenai dampak lingkungan (Amdal) pada daerah pertambangan yang mana semua unsur yang terdapat di dalam Amdal harus terpenuhi, agar kehidupan ekosistem menjadi baik dan dampak negative terhadap kegiatan pertambangan dapat ditekan seminim mungkin.

Industri pertambangan di Indonesia saat ini terus berkembang dengan pesat yang mencakup seluruh wilayah. Kegiatan usaha pertambang tidak hanya dilakukan oleh pemerintah, namun adapula sebagian dari kegiatan usaha yang dilakukan oleh pihak swasta. Pelaku usaha pertambangan harus mendapat Izin Usaha Pertambangan (IUP), yang di atur dalam Pasal 1 angkat 7 UU Minerba yang mana menjelaskan bahwa IUP adalah izin untuk melaksanakan usaha pertambangan yang mana IUP diberikan kepada badan usaha, koperasi dan usaha perseorangan.

Pertambangan yang ada di Indonesia yang sangat luas, sudah pasti menyebar di seluruh provinsi yang ada di Indonesia. Dengan jumlah pertambambangan yang menyebar tersebut negara dan pemerintah daerah harus pula mewaspadai bahwa jumlah kandungan alam pasti memiliki ukuran yang terbatas dimulai dari permukaan tanah sampai dengan kedalaman tertentu. Dalam hal tersebut berkaitan pula tentang pemberian izin usaha. Pada era otonomi daerah seperti saat ini pertanggung jawaban oleh kepala daerah langsung kepada Presiden melalui Kementerian Dalam Negeri (Kemendagri).

Dalam hal proses pelimpahan wewenang mengenai perizinan terhadap sektor SDA tidak dibarengi dengan mekanisme pengendalian terhadap kewenangan pengurusan izin. Namun hal tersebut berusah disaat dikeluarkannya Undang-Undang Nomor 23 Tahun 2014 Tentang Pemerintahan Daerah (UU Pemda), yang mana pemerintah daerah (Pemda) tidak lagi diberikan wewenang mengenai kehutanan, kelautan serta energi dan sumber daya mineral, semua menjadi kewenangan dari pemerintah pusat dan pemerintyah provinsi.

Hal tersebut dilakukan guna melaksanakan kewajiban dalam malaksanakan otonominya dan sebagai bagian dari pendistribusian penyelenggaraan kekuasaan pemerintahan negara, maka daerah-daerah memerlukan pembiyaan yang memadai dan cukup. $^{3}$ Untuk dapat meningkatkan pendapatan asli daerah (PAD) setiap daerah yang ada di Indonesia harus dapat memaksimalkan potensi SDA untuk kemakmuran masyarakat dan menyumbang untuk devisa negara, yang dapat diterapkan melalui desentralisasi fiskal. Hubungan keuangan antara pemerintah pusat dan pemerintah daerah dapat diartikan sebagai suatu sistem yang mengatur bagaimana caranya sejumlah dana dibagi di antara berbagai tingkat pemerintah, serta bagaimana caranya mencari sumber-sumber pembiayaan daerah untuk menunjang kegiatan sektor publiknya. ${ }^{4}$

Pada bagian lampiran UU Pemda pada bidang Ekonomi Sumber Daya Mineral (ESDM), menyebutkan bahwa kewenangan Pemerintah Kabupaten/Kota hanya pada bagian sub urusan enegri baru terbarukan yaitu seperti izin pemanfaatan lansung panas bumi dalam daerah kabupaten/kota. Sedangkan izin pertambangan yang meliputi IUP, IPR, izin pengelolaan dan pemurnian yang masih dalam satu provinsi adalah kewenangan pemerintah provinsi. Bahkan Kementerian ESDM mengeluarkan surat edaran Nomor: 01.E/30/djb/2015 Tentang Status Izin Usaha Pertambangan dalam rangka penanaman modal dalam negeri menjadi penanaman modal asing.

Berdasarkan hal tersebut di atas maka tim peneliti tertarik melakukan analisis

3 Eko Nuriyatman, "Bagi Hasil Pertambangan Minyak Bumi Antara Pemerintah Pusat dan Pemerintah Daerah", Jurnal Selat, 6, 2 (2019), hlm. 186.

4 Eko
Pertambangan". 
mengenai "Tinjauan Yuridis Undang-Undang Pemerintahan Daerah Tentang Kegiatan Pertambangan," yang mana akan membahas mengenai kewenangan pemda dalam hal mengeluarkan izin kegiatan pertambangan setelah terbitnya UU Pemda dan inkonsistesi anatra UU Pemda dan UU Minerba dalam hal Pertambangan. Tinjauan yuridis, yaitu menurut hukum atau daris segi hukum yang telah diakui oleh pemerintah, ${ }^{5}$ berdasarkan pengertian tersebut dapat dipahami bahwa tinjauan yuridis dapat memahami melalui segi hukum. Yang mana sifatnya adalah memaksa dan mengikat semua orang yang berada dalam sebuah wilayah pengaturan hukum tersebut.

Metode penelitian yang digunakan dalam artikel ilmiah ini adalah menggunakan metode penelitian hukum normatif (doctrinal), yang mana menurut Soetondyo Wigyosoebroto membaginya menjadi lima konsep hukum. Yang terdiri dari hukum dalam asas kebenaran dan keadilan, hukum dalam norma positif didalam peraturan perundang-undangan, hukum merupakan apa yang diputuskan oleh hakim (in concreto) dan teristemasisasi sebagai judge made law, hukum merupakan pola-pola perilaku sosial dan hukum adalah manifestasi makna-makna simbolik. ${ }^{6}$ Konsep hukum yang digunakan dalam penelitian artikel ilmiah ini adalah konsep pertama, kedua dan ketiga menurut Soetondyo Wigyosoebroto yang mana konsep hukum ini merupakan suatu norma berkaitan dengan keadilan yang diterapkan dan norma yang dibentuk melalui suatu undang-undang.

Kewenangan Pemda Dalam Mengeluarkan Izin Pertambangan

Pengesahan Undang-Undang nomor 23 Tahun 2014 Tengang Pemerintahan Daerah

5 M.Marwan dan Jimmy P, Kamus Hukum, (Surabaya: Realty Publisher, 2009), hlm. 651.

6 Setiono, Pemahaman Terhadap Metodologi Penelitian Hukum, (Surakarta: Program Studi Ilmu Hukum Pascasarjana Universitas Sebelas Maret (UNS), 2009), hlm. 20. didasarkan dengan adanya berbagai masalah dalam undang-undang sebelumnya, yaitu Undang-Undang Nomor 32 Tahun 2004 Tentang Pemerintahan Daerah. Adapun kelemahan tersebut diantaranya adalah lemahnya fungsi gubernur dan pemerintah pusat dalam melakukan pengawasan terhadap pemerintah kabupaten/kota. Pengaturan dalam bidang pertambangan merupakan salah satu rangkaian norma hukum yang pastinya berisikan norma hukum yang seharusnya dapat ditaati oleh sipemrakarsa usaha dan/atau sebuah kegiatan penegakan hukum beserta dengan instrument penegakan hukum yang berada di dalamnya. Dalam hal ini peran dari pemerintah daerah, kabupaten/kota dan pemerintah pusat merupakan pemegang peranan aktif didalam proses penegakan hukum terhadap izin pertambangan.

Perjalanan pemerintahan daerah di Indonesia memiliki tujuan yang hendak di capai seperti meningkatkan kemampuan daya saing kompetisi daerah berkaitan dengan pertumbuhan dan melakukan pelayanan terhadap masyarakat. Jika di kaitkan dengan Pasal 8 UU Minerba kewenangan dalam pemberian izin pertambangan oleh rakyat untuk jenis batubara, mineral logam, mineral bukan logam dan batuan dalam wilayah pertambangan rakyat merupakan kewenangan yang dimiliki oleh kabupaten/kota. Dengan berlakunya UU Pemda seharusnya pemerintag kabupaten/kota tidak boleh lagi mengeluarkan izin yang sifatnya baru, baik berupa pertambangan air di bawah tanah dan izin-izin lainnya yang berkaitan dengan petambangan.

Setelah dilakukan penelaahan terhadap Pasal 33 ayat (3) Undang-Undang Dasar 1945 maka dapat di simpulkan bahwa dengan dikuasainnya bumi, air dan kekuasaan alam lainnya oleh negara pemerataan terhadap pegelolaan terhadap bumi, air dan kekayaan 


\section{DATIN}

Vol 1, No 1 Februari 2020

ala mini akan dapat tercapai. ${ }^{7}$ Tujuan dari pasal tersebut memrupakan untuk mencapai kesejahteraan dan kemakmuran seluruh lapisan masyarakat. Dalam hal ini negara memiliki beberapa konsekuensi dalam hal kewajiban negara, yaitu:

1. Semua bentuk dari pemanfaatan bumi, air serta hasil yang didapat didalamnya, harus wajib secara nyata untuk dapat meningkatkan kemakmuran dan kesejahteraan masyarakat;

2. Negara harus dapat melindungi serta menjamin segala hak hak rakyat yang terdapat didalam atau di atas bumi dan air yang dapat dihasilkan secara langsung dan dapat dinikmati langsung oleh masyarakat; dan

3. Dapat mencegah segala tindakan maupun yang akan menyebabkan rakyat tidak mempunyai kesempatan atau kehilangan hak yang terdapat didalam dan diatas bumi termasuk air. ${ }^{8}$

Pasal 33 ayat (3) tersebut dipertegas pula dengan Pasal 2 ayat (2) UUPA yang merupakan dasar dari lahirnya kewengan pemerintah dalam memberikan sebuah izin yang sudah pasti berkaitan dengan pengelolaan sumber daya alam. Berkaitan dengan wewenang pemerintah $\mathrm{P}$ De Haan mengatakan bahwa wewenang dari pemerintahan tidaklah jatuh dari langit namun semuanya ditentukan oleh etika hukum. ${ }^{9}$ Namun secara teoritis Huisman dan P De Haan menyampaikan bahwa peraturan perundang-undangan yang berlaku ini diperoleh melalui tiga cara, yaitu:

1. Atribusi yang merupakan pemberian wewenang oleh pemerintahan

7 Fakih Mansour, Ledreform di Desa, (Yogakarta: Cetakan I, Read Book, 2003), hlm. 35.

${ }^{8}$ Erwiningsih Winahyu, Hak Menguasai Negara Atas Tanah, (Yogyakarta: Total Media, 2009), hlm. 9.

9 Ridwan HR, Hukum Admnistrasi Negara, (Yogyakarta: UII Pres, 2011), hlm. 103. oleh pembuat undang-undang kepada organorgan pemerintah;

2. Delegasi merupakan pelimpahan wewenang oleh pemerintahan dari suatu organ pemerintahan kepada organorgan pemerintahan lainnya; dan

3. Mandat yang terjadi ketika organ-organ pemerintahan memberikan izin kewenangannya dijalankan oleh organ lain atas namanya. ${ }^{10}$

Berdasarkan ketiga wewenang tersebut dapat disimpulkan bahwa kewenangan negara merupakan kewenangan atribusi yang di berikan oleh Undang-Undang Dasar 1945. Berdasarkan UU Pemda pemberian izin usaha pertambangan saat ini diserahkan oleh pemerintah provinsi sebagaimana yang terdapat dalam Pasal 14 ayat (1) dan (3), yang mengatur mengenai penyelenggaraan urusan dari pemerintah dalam bidang kelautan, kehutanan dan enegi serta sumber daya mineral yang telah dibagi antara pemerintah pusat dengan pemerintah provinsi dan dalam pasal ini tidak disebutkan pemerintah kabupaten/kota yang menyebabkan terhapusnya kewenangan dari pemerintah kabupaten/kota berkaitan dengan sumber daya alam.

Perkembangan kegiatan petambangan yang terjadi di Indonesia memberikan dampak yang sangat besar terhadap kegiatan pertambangan, dengan adanya kewenangan terhadap kegiatan pertambangan memiliki tujuan agar pengelolaan kegiatan pertambangan tidak terpusat dan dapat meningkatkan perekonomia dan meningkatkan PAD. Dengan semakin kuatnya perekonomian nasional serta meningkatnya kemampuan sumber daya manusia untuk mengembangkan kegiatan usaha pertambangan maka tuntutan terhadap sebuah perubahan kebijakan pengaturan kegiatan pertambangan telah menjadi agenda utama selama proses reformasi di bidang

10 Philipus M.Hadjon, dkk, Pengantar Hukum Administrasi Indonesia, (Yogyakarta: Gajah Mada University Press, 2008), hlm. 130. 
ekonomi dan hukum yang disertai dengan gerakan otonomi daerah untuk memberikan peranan yang lebih besar pada daerah saat itu.

Konsep perizinan pertambangan yang ada saat ini mampu menggantikan rejim kontrak yang diharapkan dapat memberikan dampak positif yang lebih baik bagi pemerintah yang pada akhirnya dapat meningkatkan nilai manfaat bagi kesejahteraan masyarakat. Dalam UU Minerba kewenangan pemerintah provinsi di atur dalam Pasal 7 ayat (1), sedangkan kewenangan dari pemerintah kabupaten/kota di atur dalam Pasal 8 ayat (1).

Berdasarkan analisis peneliti terhadap UU Pemda, UU ini lebih mengatur pada kewenangan gubernur dan pemerintah provinsi yang mengatur mengenai kewenangan penuh dari gubernur terhadap izin dari kegiatan pengelolaan hutan, kelautan, kehutanan dan perikanan yang berpindah kewenangan dari pemerintah kabupaten/kota kepada pemerintah provinsi berkaitan dengan pemverian izin pertambangan yang merupakan dasar dari UU Pemda. Berdasarkan pada UU Pemda pemerintah kabupaten/kota berkedudukan sebagai pelaksana fungsi dari desentralisasi dalam konsep otonomi yang seluas-luasnya dan pemerintah provinsi masih menjadi perwakilan pemerintah pusat namun kewenangan yang dimiliki oleh pemerintah provinsi menjadi lebih besar dalam bidang sumber daya alam.

\section{Inkonsistensi UU Pemda dan UU Minerba} terbaru berimplikasi terhadap penyelenggaraan berbagai urusan pemerintah dalam bidang sumber daya alam, terutama dalam sektor perikanan, kelautam, kehutanan dan sektor energi sumber daya mineral (ESDM). Yang mana bukan hanya terkait dengan kewenanangan dan wewenang namun berdampak pula pada struktur lembaga/organisasi. Pasal 404 UU Pemda menyatakan serah terima personil, pendanaan, sarana dan prasarana serta dokumen (P3D) akibat dari pembagian urusan antara pemerintah pusat dengan pemerintah provinsi dan kabupaten/kota.

Berdasarkan pada asas hukum contrarius actus pejabat pemberi izin merupakan pejabat yang berwenang dalam memberikan pengawasan dan penegakan hukum terhadap keputusan izin yang telah dikeluarkan padahal kewenangan atas pemerintaj tersebut sudah di cabut/dialihkan dan memerlukan koordinasi lebih lanjut antara pemerintah pusat dan pemerintah provinsi, kabupaten/kota. Untuk kegiatan perizinan baru berdasarkan pasa Surat Edaran Menteri Dalam Negari Nomor.120/253/SJ Tentang Penyelenggaraan Urusan Pemerintahan, yang dikelurakan pada tanggal 16 Januari 2015 pada angka tiga disebutkan secara khusus bahwa penyelenggara perizinan dalam bentuk pemberian atau pencabutan izin dilaksanakan oleh tingkatan pemerintah sesuai dengan pembagian urusan pemerintah konkuren sebagaimana yang terdapapat dalam UU Pemda.

Pelaksanaan ketiga hal tersebut harus mengutamakan kecepatan dan kemudahan proses pelayanan terhadap sebuah perizinan, serta memperhatikan seluruh proses dan tahapan yang harus di lalui. Berdasarkan surat edaran tersebut secara langsung pemerintah kabupaten/kota tidak lagi memiliki wewenang dalam menerbitkan izin karena hal tersebut merupakan wewenang dari pemerintah provinsi. Secara langsung terjadi inkonsistensi antara UU Pemda dan UU Minerba. Dikarenakan inkonsistensi terhadap dua undang-undang tersebut melahirkan konflik substansi peraturan, yaitu peraturan yang secara hierarkis memiliki kedudukan yang sejajar namun memiliki substansi peraturan yang satu bersifat lebih umum dibandingkan dengan substansi peraturan lainnya.

Dengan terjadinya inkonsistensi norma dalam ilmu hukum maka berlakulah ketentuan asas lex specialis derogate legi generalis, yaitu aturan hukum yang khusus akan mengesampingkan aturan yang umum. Pengaturan mengenai harmonisasi dan sinkronisasi dengan asas lex specialis 
derogate legi generalis merujuk pada dua undang-undang yang secara hierarkis memiliki kedudukan yang sama, namun ruang lingkup materi muatan antara peraturan per undang-undangan itu tidak memiliki kesamaan, yaitu yang satu merupakan pengaturan secara khusus dari yang lain. ${ }^{11}$

Asas tersebut jika di kaji dari sistem hukum yang dikemukakan oleh Hart tergolong dalam kategori rule of recognition yang mengatur mana aturan hukum yang mengatur aturan mana yang berlaku yang merupakan asas hukum dalam application policy dan pengaturan perizinan dalam UU Minerba lebih spesifik dari pada UU Pemda. Jika ketiga prinsip asas lex specialis derogate legi generalis ini terpenuhi, maka penerapanya dapat menyelesaikan konflik hukum yang terjadi terhadap dua undangundang tersebut mengenai kewenangan meneribitkan IUP. Berhubungan dengan perizinanan yang telah dikeluarkan oleh pemerintah kabupaten/kota sebelum dikeluarkannya UU Pemda makai zin tersebut masih berlaku sampai dengan habisnya masa izinya. Ketentuan tersebut terdapat dalam ketentuan peralihan Pasal 402 ayat (1) UU Pemda.

\section{Kesimpulan}

Kewenangan pemberian izin terhadap kegiatan pertambanag yang ada di Indonesia berdasarkan pada UU Minerba pada pemerintah kabupaten/kota namun semenjak diterbitkannya Undang-Undang Nomro 23 Tahun 2014 memberikan perubahan di dalam penerbitan izin pertambangan, yaitu pada pemerintah provinsi tidak lagi pada pemerintah kabupaten/kota berdasarkan pada UU Minerba. Dikarenakan perubahan tersebut terjadilah inkonsistensi norma dalam ilmu hukum maka didalam penerapannya berlakulah ketentuan asas lex specialis derogate legi generalis, yaitu aturan hukum yang khusus akan mengesampingkan aturan yang umum.

\section{Daftar Pustaka}

\footnotetext{
${ }^{11}$ Peter Mahmud Marzuki, Penelitian
} Hukum, (Jakarta: Edisi Revisi Prenada Media Group, 2016), hlm. 139.

\section{Buku-Buku}

HR, Ridwan. Hukum Admnistrasi Negara. Yogyakarta: UII Pres, 2011.

Mansour, Fakih. Ledreform di Desa. Yogakarta: Cetakan I, Read Book, 2003.

Marzuki, Peter Mahmud. Penelitian Hukum. Jakarta: Edisi Revisi Prenada Media Group, 2016.

M. Hadjon, Philipus, dkk. Pengantar Hukum Administrasi Indonesia. Yogyakarta: Gajah Mada University Press, 2008.

M.Marwan dan Jimmy P. Kamus Hukum. Surabaya: Realty Publisher, 2009.

Nuriyatman Eko. "Bagi Hasil Pertambangan Minyak Bumi Antara Pemerintah Pusat dan Pemerintah Daerah." Jurnal Selat, 6, 2 (2019): 184-195. DOI: 10.31629/selat.v6i2.1066.

Saleng, H.Abrar. Hukum Pertambangan. Jakarta: UII Press, 2004.

Setiono. Pemahaman Terhadap Metodologi Penelitian Hukum. Surakarta: Program Studi Ilmu Hukum Pascasarjana Universitas Sebelas Maret (UNS), 2009.

Winahyu, Erwiningsih. Hak Menguasai Negara Atas Tanah. Yogyakarta: Total Media, 2009.

Yamin, Muhammad. Naskah Persiapan Undang-Undang 1945. Djakarta: Jilid Pertama (Cetakan Kedua), Siguntang, 1971.

\section{Undang-Undang}

Undang-Undang Dasar 1945.

Undang-Undang Nomor 5 Tahun 1960 Tentang Peraturan Dasar Pokok-Pokok Agraria. 
Undang-Undang Nomor 4 Tahun 2009

Tentang Pertambangan Mineral dan Batu Bara.
Undang-Undang Nomor 23 Tahun 2014 Tentang Pemerintahan Daerah. 